\title{
Új szakaszba léptek a magyar tőkebefektetések Kárpátalján?
}

\section{Have Hungarian investments in Transcarpathia entered a new phase?}

\author{
IMRE GABRIELLA
}

IMRE Gabriella: tanársegéd, Budapesti Gazdasági Főiskola, Külkereskedelmi Főiskolai Kar, Világgazdaság és Nemzetközi Kereskedelem Tanszék; imre.gabriella@kkk.bgf.hu

KULCSSZAVAK: Kárpátalja, külföldi működőtőke-befektetés, magyar kis- és középvállalatok

ABSZTRAKT: Noha Ukrajna és ezen belül Kárpátalja sosem szerepelt a Magyarországról kiáramló tőkebefektetések legfontosabb célpontjai között, 2009-ben hazánk a negyedik helyet foglalta el a határ menti ukrán megye gazdaságában tőkét befektető országok rangsorában, és 10\% körüli részesedésével megelőzte Ausztriát. A kárpátaljai magyar befektetések igazi érdekességét ugyanakkor nem a befektetett tőke mennyisége, hanem a befektető vállalatok száma és mérete adja: az ITD Hungary 2009-es adatai szerint 254 vállalat müködött magyar tőkével a térségben, ami a befektetők között a magyar tőketulajdonban lévő kis- és középvállalatok magas arányát valószínűsíti.

A tanulmány célja, hogy feltárja a Kárpátaljára tőkét kihelyező magyarországi vállalatok jellemzőit, azonosítsa a külföldi befektetést lehetővé tevő versenyelőnyök forrását és a legfontosabb befektetési motivációkat. A 2010-ben végzett kérdőíves kutatás során a Kárpátalján befektető magyar vállalatok tapasztalatait is feltérképeztem. A tanulmány első része néhány, a vállalatok nemzetköziesedési folyamatával kapcsolatos elméletet tekint át. A kérdőíves felméréshez elsősorban Dunning eklektikus paradigmája szolgált kiindulópontként, amely bizonyos megszorításokkal alkalmazható a kisebb méretű vállalatok tőkekihelyezéseire is. A Kárpátaljára irányuló magyar befektetések általános jellemzőinek áttekintését követően röviden összegzem a kérdőíves kutatás eredményeit.

Az Európai Unió külső határa mentén elhelyezkedő terület periferikus jellege, Magyarországhoz való közelsége folytán és az itt élő jelentős számú magyar kisebbségnek köszönhetően sajátos versenyelőnyöket nyújt a magyar kis- és középvállalatok számára, amelyek azonban a befektetési környezet európai normáktól eltérő jellemvonásai miatt sajátos kihívásokkal, problémákkal szembesülnek.

Gabriella IMRE: assistant lecturer, World Economics and International Trade Department, College of International Management and Business, Budapest Business School; imre.gabriella@kkk.bgf.hu

KEYWORDS: Transcarpathia, foreign direct investment, Hungarian small and medium-sized enterprises

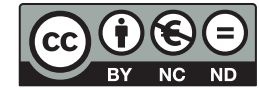


ABSTRACT: While Transcarpathia has never been the main destination for Hungarian outward foreign direct investment (FDI), in 2009 Hungary became the fourth largest investor in the economy of the Ukrainian border county, accounting for a share of 10 per cent of total capital investments. The really interesting aspect of Hungarian investments in Transcarpathia is not the amount of the invested capital but the number and size of the investing companies. According to the data provided by the Hungarian Investment and Trade Development Agency, the number of Transcarpathian companies with Hungarian participation increased to over 250 in 2009, indicating a high proportion of Hungarian-owned small and medium-sized enterprises (SMEs) among the investors.

The aim of the paper is to explore the characteristics of the Hungarian companies investing in Transcarpathia, to identify both the source of their competitive advantages allowing them to expand abroad and their most important investment motives.

In the first part of the paper some theories explaining the internationalisation process of the companies involved are reviewed. The author has been relying mainly on the eclectic (or OLI) paradigm of John Dunning. The relevance of this paradigm was confirmed for SMES as well. When examining the investment motives of Hungarian companies, several other theories should be taken into account because they reveal further issues concerning FDI activities.

Following a short review of the general characteristics of the Hungarian investments in Transcarpathia, the paper briefly presents the results of a survey carried out in 2010. Interviews revealed that in many cases, statistically Hungarian capital invested by the mid-nineties in Transcarpathia can be explained by the phenomenon of the so-called round-tripping FDI. As a cumulative result of the strengthening of Hungarian companies, the consolidation of Ukrainian market economic conditions and the tightening of border controls, the significance of roundtripping investments is gradually declining, and Hungarian FDI allocated for real investment purposes increasingly took its place in Transcarpathia.

The survey revealed that investment decisions by Hungarian entrepreneurs have been primarily motivated by market-oriented factors: The re-localisation of production and sales activities abroad opened up not only the Ukrainian but also the Russian markets due to the internal tariff concessions of the Commonwealth of Independent States. The specific advantages of Hungarian companies investing in Transcarpathia are related to a higher level of technology and to more developed production processes. All investors face a completely different, or at least unusual, business environment in Transcarpathia. In this risky and uncertain business environment, the advantages of Hungarian companies compared to their stronger Western European (for example, Austrian) competitors arise from the fact that - due to their former business and personal relations with the members of the Hungarian minority living in the region - they possess exclusive market information which hedges successful investments. The comparative advantages offered by Transcarpathia can be exploited mainly by a group of investing companies familiar with local conditions, aware of the unwritten rules of the Ukrainian economy or - with the help of reliable partners - can find their way in the labyrinth of legal uncertainties.

According to the survey, geographical proximity can be a key factor to receive information about the market because most Hungarian firms investing in Transcarpathia have their headquarters in Szabolcs-Szatmár-Bereg county, immediately adjacent to the Ukraine. In the case of FDI originating from the more distant regions of Hungary, generally personal or business ties linking the investor firms to the members of the Hungarian minority in Transcarpathia can be detected.

Transcarpathia which is located on the external border of the European Union provides unique comparative advantages for Hungarian SMEs due to its geographical proximity, to its peripheral character and to the significant number of ethnic Hungarians living in the region as a minority. However, companies are facing particular challenges and problems arising from the differences in the investment environments in the two countries at the same time. In order to increase Hungarian FDI in Transcarpathia and the number of SMEs to consider the Ukrainian stretch along the border as a promising investment opportunity, above all the business climate generally characterising the Ukraine should become more investment-friendly. This can be achieved primarily not by laws intended to attract foreign investors, but by a clearly visible 
presence of conditions identified with market economies and a more coherent and effective implementation of various reforms. The Ukraine is potentially a promising investment market for Hungarian companies, especially as just by size it is as big as all the other neighbouring countries combined.

It is expected that after the current political and economic crisis growth of the Ukrainian economy will exceed the European average from which - under appropriate conditions - also the Hungarian entrepreneurs can benefit particularly in such sectors as agriculture, information technology, the service sector, the food industry and mechanical engineering. Assuming that the Hungarian-Ukrainian border will remain the external border of the European Union for a longer period, the development of cross-border economic co-operation is a key issue for both countries.

\section{Bevezetés}

Ukrajna és a határ menti ukrán terület, Kárpátalja sosem szerepelt a Magyarországról kiáramló tőke legfontosabb befektetési célpontjai között, mégis a befektető vállalatok száma és Kárpátalja sajátos adottságai miatt figyelmet érdemel a térségbe irányuló hazai befektetői aktivitás. Az ITD Hungary 2009-es adatai szerint 254 vállalat működött magyar tőkével a térségben, ami a tőkét kihelyező vállalatok között a kis- és középvállalatok nagy arányát valószínűsíti. Az Európai Unió külső határa mentén elhelyezkedő terület periferikus jellege és Magyarországhoz való közelsége folytán, valamint az itt élő, jelentős számú magyar kisebbségnek köszönhetően egyedi versenyelőnyöket nyújt a magyar vállalatok számára, amelyek azonban a befektetési környezet sajátosságai miatt kihívásokkal, problémákkal is szembesülnek.

A tanulmány ${ }^{1}$ első részében áttekintem a vállalatok müködőtőke-befektetéseinek indokait magyarázó, az empirikus vizsgálat alapjául szolgáló fontosabb elméleteket. A Kárpátaljára irányuló magyar működőtőke-befektetések általános jellemzése után összefoglalom a befektető magyar vállalatok körében 2010-ben végzett kérdőíves kutatás eredményeit. A Kárpátaljára irányuló befektetések kapcsán lehetőség nyílik a hazai kis- és középvállalati kör külföldi terjeszkedésének vizsgálatára, amellyel eddig a kis- és középvállalatoknak a magyar kiáramló működőtőke-állományból való csekély részesedése miatt csak kevés kutatás foglalkozott.

A mai Kárpátalja (hivatalos nevén Zakarpatszka oblaszty, vagyis Kárpátontúli terület) Ukrajna legnyugatibb adminisztratív egységeként mintegy 12800 $\mathrm{km}^{2}$-en terül el az ország délnyugati csücskében. ${ }^{2}$ Csak egyötöde síkság, négyötödét a Kárpátok vonulatai alkotják, amelyek természetes határként választják el a területet az ország többi részétől. Kárpátalja északkeleten két ukrán régióval (Lviv, Ivano-Frankivszk), délen Romániával és Magyarországgal, nyugaton pedig Szlovákiával és Lengyelországgal határos. A határ menti ukrán terület tizenhárom kisebb közigazgatási egységre, a beregszászi, a perecsenyi, a huszti, a rahói, az ilosvai, a szolyvai, a munkácsi, a técsői, a nagybereznai, az ungvári, a nagyszőlősi, a volóci és az ökörmezői járásra oszlik. Területén tizenegy város (öt megyei jogú: Csap, Ungvár, Munkács, Huszt és Beregszász), tizenkilenc vá- 
rosi jellegű település (mezőváros, nagyközség), valamint 579 község és kistelepülés található. Székhelye Ungvár (Uzhgorod).

Kárpátalja Ukrajna egyik legkisebb régiója, az ország összterületének 2,1\%-án. A 2014. március 1-jei becslések alapján népessége 1,257 millió fö (az összlakosság 2,7\%-a), amelynek 37\%-a városokban, 63\%-a vidéken él. A 2001-es népszámlálás adatai szerint a területen több mint hetven etnikai csoport található. A lakosság legnagyobb része ukrán $(80,5 \%)$, a legnagyobb számú kisebbség a magyar $(12,1 \%)$, de a területen élnek még románok (2,6\%), oroszok (2,5\%) romák (1,1\%), szlovákok ( $0,5 \%)$ és németek is $(0,3 \%)$. A terület önálló történelmi fejlődéssel és más irányú kötődésekkel rendelkezik, mint Ukrajna déli és keleti része, hiszen a 2. világháborúig az ukrán területektől függetlenül fejlődött. A 20. század folyamán Kárpátalja különböző államalakulatokhoz tartozott: az Osztrák-Magyar Monarchiához (1918-ig), Magyarországhoz (1918-19; 1939-1944), Csehszlovákiához (1920-1938), az Ukrán Szovjet Szocialista Köztársasághoz (1945-1991), a Szovjetunió felbomlása óta pedig a független ukrán állam adminisztratív egysége.

\section{Elméleti alapok}

A külföldi működőtőke-áramlás motivációinak magyarázatára a hatvanas évektől kezdődően számtalan elmélet született, melyek közül elsősorban John Dunning 1977-ben publikált eklektikus paradigmájára támaszkodom. Az eklektikus elmélet előfeltevése, hogy a külföldi működőtőke-áramlást nem lehet egyetlen tényezővel megmagyarázni. A modell három csoportba gyüjtötte azokat a tényezőket, amelyek egy vállalatot külföldi működőtőke-befektetésre ösztönöznek:

- a befektető vállalathoz kötődő tulajdonspecifikus előnyök,

- a befektetés célországát jellemző elhelyezkedési előnyök és

- a termelés vállalaton belüli megszervezéséből származó internalizációs előnyök.

Az eklektikus paradigma eredetileg a multinacionális vállalatok külföldi tevékenységét kívánta magyarázni, de a későbbi kutatások minden egyes előny fontosságát és a befektetési folyamatban betöltött szerepét igazolták a kis- és középvállalatok körére is (Dunning 1993).

A működőtőke-befektetések indítékainak vizsgálata során az eklektikus paradigma mellett más elméleteket is célszerü figyelembe venni, mert ezek a külföldi működő tőke további összefüggéseire világítanak rá. Az Uppsala-iskola fokozatos nemzetköziesedési modellje szerint a vállalatok néhány kivételes esettől eltekintve fokozatosan növelik nemzetközi szerepvállalásukat. A nemzetköziesedés kulturálisan közeli, szomszédos, kevésbé igényes, hasonló ízléssel rendelkező piacokon indul meg, rendszerint exporttal. Később az export kiegészül a szerződéses megállapodások bizonyos formáival, kereskedelmi képviseletek létesítésével és végül a külföldi termeléssel (Johanson, Vahlne 1990; Johanson, Wiedersheim-Paul 1975). 
A befektetési fejlődési pálya (investment development path) paradigmája szerint egy ország esetén a kiáramló és beáramló működőtőke-állomány különbsége elsősorban a gazdasági fejlettség (az egy före jutó GDP) függvénye. A modell szerint az országok öt fejlődési szakaszon mennek keresztül. Az első szakaszban a beáramló és kiáramló működő tőke állománya egyaránt elenyésző. A következő szakaszban a beáramló működő tőke növekedni kezd, miközben a kiáramló múködő tőke továbbra is kismértékű marad. A harmadik szakaszban lévő országokat a beáramló működő tőke növekedési rátájának folyamatos csökkenése jellemzi, míg a kiáramló működő tőke növekedési rátája emelkedik, és ez elsősorban olyan szomszédos országokba irányul, amelyek a befektetési fejlődési pálya előző szakaszaiban vannak. A befektetések célja jellemzően a piacszerzés. A negyedik szakaszban a kiáramló múködőtőke-befektetések állománya már meghaladja a beáramlót vagy a kiáramló működő tőke növekedési rátája magasabb, mint a beáramlóé. Az ötödik szakaszban a kiáramló és beáramló müködő tőke állománya is folyamatosan nő, mennyiségük közel azonos (Dunning, Narula 1996).

Elemzésem általános elméleti keretét ez a három elmélet biztosítja. Dunning eklektikus paradigmáját azért is célszerü kiegészíteni a másik két elmélettel, mert a ljubljanai egyetemen folytatott kutatások szerint mind a skandináv iskola fokozatos nemzetköziesedési modellje, mind a befektetési fejlődési pálya paradigmája kiválóan alkalmas az egykori átmeneti gazdaságokból származó vállalatok működőtőke-tevékenységének magyarázatára (Hardi 2001; Svetličič 2003; Svetličič, Jaklič, Burger 2007).

\section{A magyar müködő tőke szerepe Kárpátalja gazdaságában}

1995 és 2014 áprilisa között a Kárpátalja gazdaságába befolyt külföldi működőtőke-állomány elérte a 406,6 millió USD-t. A globális pénzügyi válság idején, 2009-ben kismértékű visszaesés volt tapasztalható, 2010-ben azonban újra nőtt a régióban befektetett működő tőke összege. A működőtőke-befektetések ágazati megoszlását tekintve az ipar áll az élen, ahova 2011-ben az összes külföldi működő tőke több mint 78\%-a (273 millió USD) irányult. Az iparágakon belül a feldolgozóiparba érkezett a legtöbb tőke (265,5 millió USD), amelyből a gépgyártás 93,5 millió USD-vel részesült. Az ipart a szállítmányozás és a távközlés követte, ahová a külföldi tőke 8,5\%-a érkezett. $5 \%$ feletti részesedéssel még az ingatlanközvetítés rendelkezett, a többi szektor részaránya elenyésző volt. Az ipar súlyát bizonyítja, hogy 2011-ben a külföldi forrásból üzemelő iparvállalatok a megyében értékesített összes termék 76\%-áért voltak felelősek (Kárpátaljai Magyar Vállalkozók Szövetsége 2013). Az elmúlt másfél évtizedben a külföldi beruházások legfontosabb célpontja az ungvári járás, ezen belül elsősorban Ungvár volt a képzett munkaerőnek és a viszonylag jól felszerelt vállalatoknak 
köszönhetően. Hasonló okok miatt telepedett meg a külföldi müködő tőke Munkácson és annak környékén.

Kárpátalja gazdaságába 53 országból érkeznek működőtőke-befektetések, de ezek közel $60 \%$-át öt ország adja. Magyarország a Kárpátalján befektető országok rangsorában a 2009. januári adatok szerint még 34,7 millió USD befektetett tőkével a negyedik helyen állt Japán, az Egyesült Államok és Németország mögött. A globális pénzügyi válságot követően Magyarország befektetői pozíciója romlott, hazánk a 2014. áprilisi adatok szerint 23,7 millió USD tőkerészesedéssel már csak a nyolcadik helyet foglalta el a befektető országok rangsorában (1. táblázat).

A kárpátaljai magyar működőtőke-befektetések 1995 és 2000 között növekedtek a legdinamikusabban, amikor a befektetett tőke mennyisége meghétszereződött. Noha 2000 és 2009 között folytatódott a Kárpátalján befektetett magyar működőtőke-állomány emelkedése, a növekedés dinamikája megtört, 2010-től kezdődően pedig az állomány csökkenéséről tanúskodnak az adatok (2. táblázat). A Magyar Nemzeti Bank és a Kárpátaljai Statisztikai Hivatal adatainak összevetése alapján készített becslések megerősítik, hogy míg a kilencvenes években az ukrajnai magyar befektetések többsége a határ menti ukrán régió gazdaságában történt (Ludvig 2007), addig 2009-ben az Ukrajnában befektetett működő tőkének már csupán kb. 7\%-a irányult Kárpátaljára. ${ }^{3}$

1. táblázat: Kárpátalja külföldi működőtőke-állományának megoszlása befektető országok szerint Geographical distribution of foreign direct investment inward stock in Transcarpathia

\begin{tabular}{lrr|lrc}
\hline \multicolumn{2}{c}{2009} & & \multicolumn{3}{c}{2014} \\
\hline \multicolumn{1}{c}{ Befektetó országok } & millió USD & \multicolumn{1}{c|}{$\%$} & Befektető országok & millió USD & $\%$ \\
\hline Japán & 48,1 & 13,5 & Japán & n.a. & n.a. \\
Egyesült Államok & 47,9 & 13,5 & Ausztria & 40,7 & 10,0 \\
Németország & 42,7 & 12,0 & Ciprus & 38,5 & 9,5 \\
Magyarország & 34,7 & 9,7 & Németország & 38,1 & 9,4 \\
Lengyelország & 33,1 & 9,3 & Lengyelország & 37,0 & 9,1 \\
Ausztria & 29,8 & 8,4 & Egyesült Államok & 31,0 & 7,6 \\
Hollandia & 22,2 & 6,2 & Hollandia & 25,6 & 6,3 \\
Olaszország & 16,0 & 4,5 & Magyarország & 23,7 & 5,8 \\
Svájc & 9,9 & 2,8 & Olaszország & 17,7 & 4,4 \\
Egyéb & 60,2 & 16,9 & & & \\
\hline Összesen & 344,6 & 100,0 & Összesen & 406,6 & 100,0 \\
\hline
\end{tabular}

Forrás: http://www.uz.ukrstat.gov.ua

2. táblázat: A magyar működőtőke-befektetések állományának alakulása Kárpátalján Hungarian foreign direct investment stock in Transcarpathia

\begin{tabular}{cccccccccccc}
\hline Év & 1995 & 2000 & 2005 & 2006 & 2007 & 2008 & 2009 & 2010 & 2011 & 2012 & 2014 \\
\hline Millió USD & 2,4 & 16,4 & 25,8 & 27,2 & 30,2 & 32,3 & 34,7 & 32,0 & 31,7 & 28,9 & 23,7 \\
\hline
\end{tabular}

Forrás: Cтатистичний щ̧орічник 3акарпатmя 2007; http://www.uz.ukrstat.gov.ua 
Mindebből arra következtethetünk, hogy napjainkban az Ukrajnában befektető magyar vállalatoknak nem Kárpátalja az elsődleges célpontjuk, hanem a fejlettebb ipari termeléssel rendelkező távolabbi ukrán megyék. Kárpátalja alacsony részesedése az ukrajnai magyar befektetések összegéből mindenekelőtt azzal magyarázható, hogy a nagyobb tőke befektetésére és a nagyobb kockázatok elviselésére képes magyarországi nagyvállalatok elsősorban nem a határ menti területeken létesítenek leányvállalatokat, hanem az ország belső területein.

A kérdőíves felmérést megelőzően készített interjúkból világossá vált, hogy a kilencvenes években a kárpátaljai vállalkozásokba érkező, statisztikailag magyar nemzetiségűként nyilvántartott tőkét sok esetben a körbeáramló tőke (round-tripping FDI) jelensége magyarázza. Ez azt jelenti, hogy a kárpátaljai magyar vagy magyar kapcsolatokkal rendelkező vállalkozók tőkéjüket magyarországi vállalatba fektették, majd az immár magyar nemzetiségű tőkét Kárpátalján müködő saját vállalatukba áramoltatták vissza, hogy a külföldi tőkével működő vállalkozások számára Ukrajnában biztosított adókedvezményeket megszerezzék. ${ }^{4}$ Ez a befektetői magatartás egyáltalán nem újszerü, hiszen az Ukrajnába érkező működő tőke forrásországai között előkelő helyen szerepelnek az adóparadicsomok (Ciprus és a Brit Virgin-szigetek), amelyek feltételezhetően korábban kimenekített orosz és ukrán tőkét csatornáznak vissza az ukrán gazdaságba. A kilencvenes években ráadásul a magyar-ukrán határ nyitottabbá válása is elősegítette a tőkeáramlás e sajátos formájának megjelenését.

A magyar működő tőkének látszó, eredetileg azonban ukrán tőke ugyan napjainkra sem tűnt el Kárpátalja gazdaságából, részaránya azonban jóval kisebb, mint a kilencvenes években, mivel az ukrán kormány a külföldi tőkével működő vállalkozások számára igénybe vehető adókedvezményeket megszüntette. A jogszabályi változásoknak, az ukrán és a kárpátaljai gazdaság ezredfordulótól kezdődő egyidejü növekedésének és az ugyan ellentmondásokkal terhelt, de mégis megszilárdulóban lévő piacgazdasági viszonyoknak köszönhetően az ezredfordulótól a ténylegesen (nem csak statisztikailag) magyar müködő tőke is megjelent a térségben.

\section{A kárpátaljai magyar befektetők körében végzett kérdőíves vizsgálat}

Magyarország a kárpátaljai lakosság kb. 12\%-át kitevő magyar kisebbségnek köszönhetően privilegizált helyet foglal el az ukrán régió kereskedelmi és tőkekapcsolataiban. A 2010 nyarán és őszén végzett kutatásom a tőkekapcsolatokra koncentrált. Az empirikus vizsgálat gerincét a határ menti ukrán területen befektető magyarországi vállalatok vezetőit és a kárpátaljai leány- vagy vegyes vállalatok ügyvezető igazgatóit kérdőívvel megkereső adatfelvétel jelentette. A kérdések a befektető magyar vállalat vagy a kárpátaljai leány- vagy vegyes vál- 
lalat általános jellemzői (székhely, tevékenység, méret, tulajdonosi viszonyok) mellett elsősorban - Dunning eklektikus paradigmája alapján - a befektetési motivációkra, a magyar cégek külföldi befektetést lehetővé tevő tulajdonspecifikus előnyeire és Kárpátalja magyar befektetők számára kiaknázható helyspecifikus előnyeire koncentráltak. (Az internalizációs előnyök - tekintettel arra, hogy zömében egy vagy néhány külföldi leányvállalattal bíró kis- és közepes méretű vállalkozásokról van szó - nem játszottak fontos szerepet.) A kutatás fel kívánta tárni a magyar tőkével működő kárpátaljai vállalatok legfontosabb értékesítési piacait és a vállalati működés szempontjából nehézséget jelentő tényezőket is.

A Kárpátaljai Statisztikai Hivatal 2009. eleji adatai alapján a magyar beruházások értéke elérte a 34,7 millió USD-t, ami 254 magyar tőkével működő vállalat tevékenységéhez volt köthető. Mivel az ukrán régióban befektetett magyar működő tőke állománya a következő években csökkent, ezen kívül pedig a magyar tőkét bevonó vállalkozások egy részében csak statisztikai értelemben magyar nemzetiségű a tőke, a kérdőíves felmérés körülbelül 200 magyar tőkével működő vállalkozással számolt. Ezek közül 28 vállalkozást kerestem meg személyesen vagy telefonon, azonban - a kérdőives megkérdezés előtt lebonyolított interjúk alapján - mindössze 20 vállalkozás esetében lehetett egyértelműen kizárni a körbeáramló tőke jelenségét. Ezek a vállalatok kerülhettek be a mintába, mert a kérdőív alapjául szolgáló, a működőtőke-áramlást magyarázó nemzetközi elméletek a körbeáramló tőke eseteire nem alkalmazhatók. A kutatás a megkérdezett vállalatok alacsony száma miatt nem reprezentatív, de hiánypótló jellegü, mivel a vállalatok nehéz elérhetősége, alacsony válaszadási hajlandósága és a térséget a kilencvenes évek óta jellemző illegális tevékenységek miatt a kárpátaljai magyar befektetők motivációit átfogóan felmérő kutatásra eddig nem került sor.

\section{A Kárpátalján befektető magyar vállalatok jellemzői}

A Szabolcs-Szatmár-Bereg megyében székhellyel rendelkező vállalatok az ország más területén müködő vállalkozásoknál gyakrabban végeznek tevékenységet Kárpátalján. A megkérdezett 20 vállalat közül 8 vállalatnak a Kárpátaljával közvetlenül szomszédos Szabolcs-Szatmár-Bereg megyében (döntően Nyíregyházán) volt a központja, további 4 cég Budapesten müködik (1. ábra). Kárpátalja földrajzi közelsége tehát fontos szerepet játszott a befektetési döntésekben: a megkérdezett befektető vállalatok felének a magyar-ukrán határtól 2-3 órányira, 80-170 km-es távolságban található a székhelye, ami - a határátlépés nehézségeit nem számítva - könnyebb kapcsolattartást tesz lehetővé az anyavállalat és leányvállalat, vagyis a befektető magyar cég és a magyar tőkerésszel működő kárpátaljai vegyes vállalat között.

Foglalkoztatotti létszám alapján a befektető vállalatok többsége (14 vállalat) kis- és közepes méretü, a mintában mindössze hat nagyvállalat fordult elö, 
1. ábra: A Kárpátalján befektető, mintában szereplő magyar vállalatok székhelyei Headquarters of sampled Hungarian companies investing in Transcarpathia

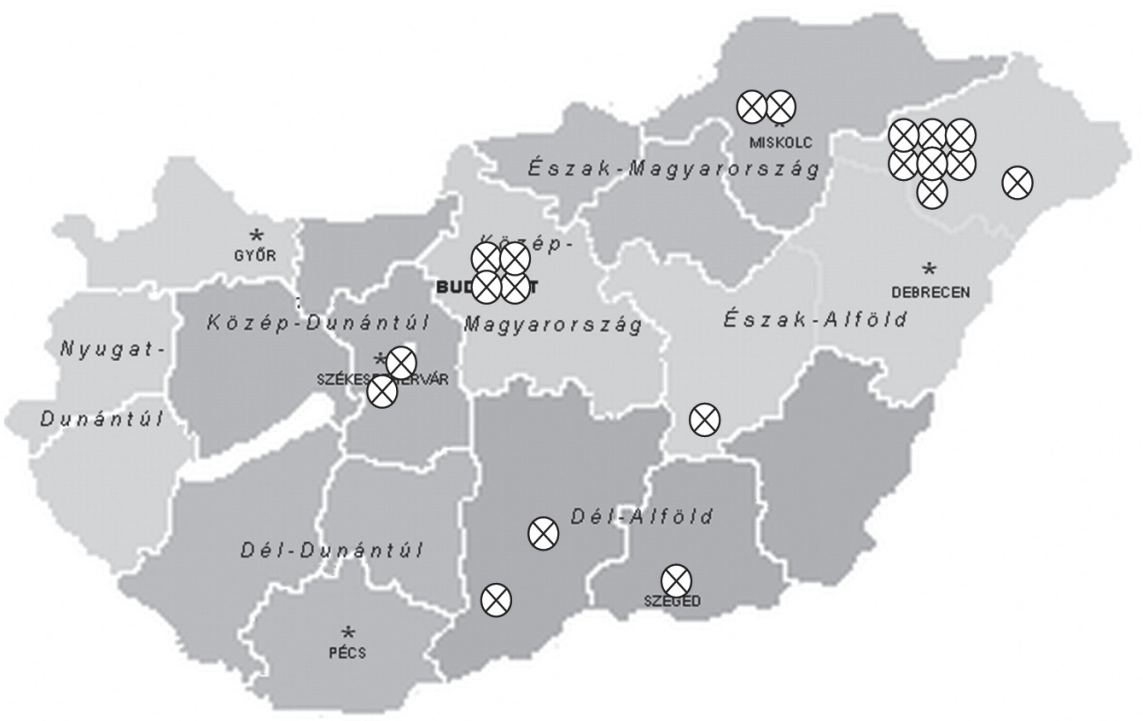

ami igazolja a magyar tőkével működő vállalatokról korábban megfogalmazott feltevést. A tulajdonosi szerkezetet vizsgálva kiderül, hogy 16 cég kizárólagos, míg két vállalat többségi magyar tulajdonban van. A megkérdezett vállalatok közül mindössze két vállalat hajtotta végre a kárpátaljai befektetést külföldi tulajdonú cég magyarországi leányvállalataként. A mintában tehát a magyar tulajdonú közepes és nagyvállalatok, valamint a magyar tulajdonú kis- és közepes vállalatok domináltak.

\section{A befektetést lehetövé tevő tulajdonspecifikus előnyök}

A termelő és szolgáltató vállalatok (a mintában 10, illetve 4 cég) kárpátaljai tőkekihelyezéseiben elsősorban a müszaki-technológiai ismeretek, továbbá a termelési és szolgáltatási tapasztalatok biztosítottak versenyelőnyt a helyi piaci szereplőkkel szemben (2. ábra). A tőkét kihelyező magyar vállalatok zöme ugyanis az 1989-1997 közötti időszakban létesült, részben a már korábban is működő állami nagyvállalatok privatizáció során történő újraszervezésével, tehát a befektető cégek komoly műszaki tudással, termelési tapasztalattal, ismert márkákkal, esetenként szabadalmi védettséget élvező termékekkel rendelkeztek. A magyar vállalatok tapasztalatai és technológiai ismeretei a modernizáció lehetőségét kínálták Kárpátalja alacsony hatékonysággal működő gazdasági ágazatai számára. Az ukrán (ezen belül is az országos átlagnál alacsonyabb fejlettségű kárpátaljai) piacon megvalósított működőtőke-befektetések ténye ugyanakkor arra enged következtetni, hogy a befektető magyar kis- és középvál- 
2. ábra: A Kárpátalján befektető magyar vállalatok tulajdonspecifikus előnyei Ownership-specific advantages of Hungarian firms investing in Transcarpathia

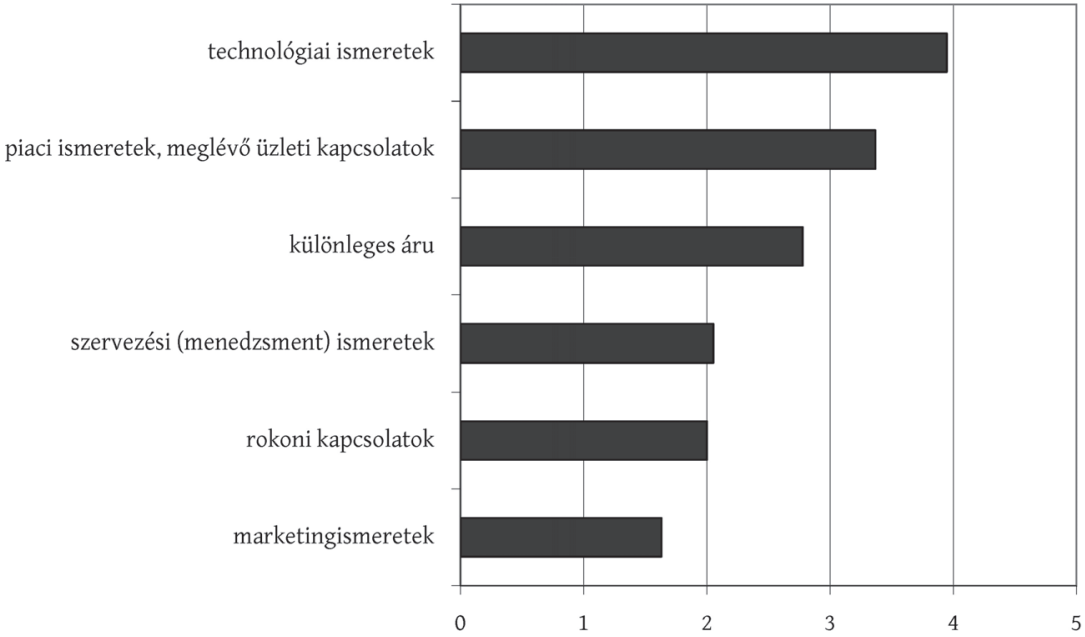

Megjegyzés: A kérdöiven a válaszadók 1 és 5 között értékelhették, hogy mely, a vállalat által birtokolt előny tette lehetővé a kárpátaljai terjeszkedést. Az 1-es érték azt fejezi ki, hogy az adott előny nem volt meghatározó, az 5-ös érték pedig azt jelenti, hogy az adott ismeret döntö szerepet játszott a tókekihelyezésben, mert általa a befektetö vállalat olyan elönyhöz jutott, amellyel a térségben müködö más vállalatok nem rendelkeztek. Az ábra a húsz vállalat válaszainak átlagos értékeit tünteti fel.

lalatok és nagyvállalatok technológiai ismeretekhez és tapasztalathoz köthető tulajdonspecifikus előnyei csupán ahhoz voltak elegendők, hogy egy kevésbé nagy fogyasztói igényeket támasztó piac vállalatainak hasonló típusú előnyeit felülmúlják.

Az értékesítéssel foglalkozó leány- és vegyes vállalatokban (6 vállalat) a jó minőségü és a fejlettebb országok termékeinél olcsóbb áruk nyújtottak a magyar cégek számára egyedi és fenntartható kompetitív előnyöket. A magyar befektetők tulajdonspecifikus előnyei közül ki kell emelni még a térség gazdasági szereplőivel korábban kiépített üzleti (esetlegesen rokoni) kapcsolatokat is. A szabolcsi vállalatok dominanciája a befektetők között így elsősorban arra vezethető vissza, hogy földrajzi közelségüknek és korábbi kapcsolataiknak köszönhetően szélesebb körü és pontosabb piaci információkkal rendelkeztek az ország más pontjain müködő (esetlegesen tőkeerősebb) versenytársaiknál. A szervezési, menedzsment- és marketingismeretek csak a nagyvállalatok esetében számítottak fontos tulajdonspecifikus előnynek.

\section{Befektetési motivációk}

A magyar vállalatok kárpátaljai tőkekihelyezéseit döntően piaci tényezők motiválták (3. ábra): a befektető vállalatok a 46 millió főt számláló ukrán piachoz 


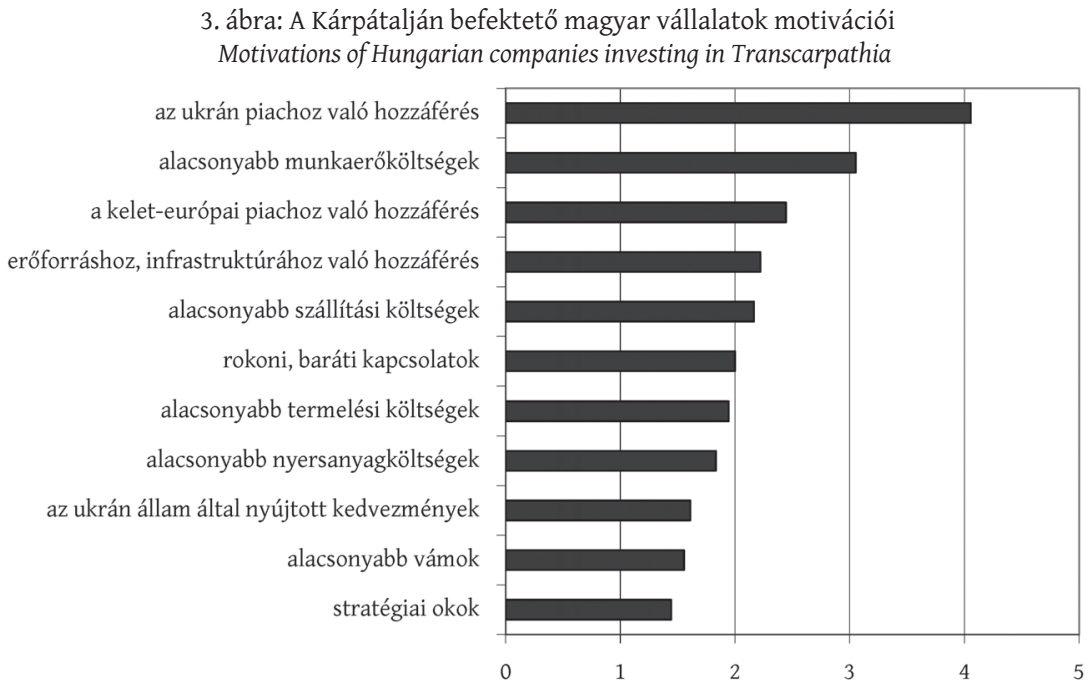

Megjegyzés: A kérdöiven a válaszadók 1 és 5 között értékelhették, hogy melyek voltak a befektető vállalat motivációi a kárpátaljai terjeszkedés során. Míg az 1-es érték azt fejezi ki, hogy az adott motiváció nem volt meghatározó, addig az 5-ös érték azt jelenti, hogy az adott motiváció döntő szerepet játszott a tókekihelyezésben. Az ábra a húsz vállalat válaszainak átlagos értékeit tünteti fel.

szerettek volna hozzáférni. A hazai befektetők egy részének céljai között a kelet-európai (elsősorban orosz) piacra történő belépés is szerepelt. A piac mérete mellett a magyar befektetőket leginkább az ukrajnai viszonylatban is olcsó munkabérek vonzották (a kárpátaljai átlagbér 2010-ben az ukrán átlagbér $82 \%$-át tette ki). A befektetési döntésekben - a vállalat tevékenységének jellegétől függően - az alacsony szállítási, termelési vagy infrastrukturális költségek játszottak további szerepet, ezek azonban a munkaerőköltségeknél sokkal kisebb jelentőséggel bírtak. Az ukrán állam által nyújtott kedvezmények és az alacsonyabb vámok szerepe elhanyagolható volt és a stratégiai indokok sem játszottak döntő szerepet a befektetési döntésekben, mivel a megkérdezett befektető vállalatok között nagy arányban voltak kis- és középvállalatok, amelyek Kárpátalján kívül más külföldi régiókba nem helyeztek ki tőkét. Bár a magyar tőkebefektetések hátterében sok esetben rokoni szálak is húzódnak, ezek a kapcsolatok önmagukban (a piaci motivációk és a térség adottságai nélkül) nem szolgáltattak volna elégséges alapot a beruházások megvalósítására.

A kis- és középvállalatok, valamint a nagyvállalatok motivációi közt nem mutatható ki lényeges különbség: a piachoz való hozzáférés vállalatmérettől függetlenül a tőkekihelyezések legfontosabb indokának tekinthető. Emellett a kisebb méretű vállalatok esetében nagyobb hangsúlyt kaptak a rokoni-baráti kapcsolatok, de az alacsony munkaerő- és szállítási költségek szintén számukra voltak fontosabbak. 


\section{Kárpátalja helyspecifikus előnyei}

A működőtőke-befektetéseket az ukrán régió további (elsősorban magyar befektetők számára kiaknázható) adottságai tették még vonzóbbá a hazai vállalatok számára (4. ábra). A vállalatvezetők a térség nyújtotta egyedi előnyök közül elsősorban a határhoz való közelséget emelték ki. A schengeni határőrizeti rendszer bevezetése ugyan nehezítette a Kárpátalján működő leány- vagy vegyes vállalattal való kapcsolattartást, de a vállalatok többsége képes volt alkalmazkodni a kialakult helyzethez. A földrajzi közelség mellett a megkérdezett vállalatok zöménél (18 vállalat) a magyar kisebbség jelenléte és a nyelvi akadályok hiánya játszott döntő szerepet abban, hogy Ukrajnán belül Kárpátalját választották telephelyként. A vizsgált magyar vállalatok (egy külföldi cég magyarországi leányvállalatától eltekintve) nem is fektettek be máshol Ukrajna területén. A kis távolság tehát nemcsak fizikai, hanem kulturális értelemben is fontos volt a magyar vállalkozások számára, alátámasztva ezzel a fokozatos nemzetköziesedés skandináv modelljét.

A hasonló mentalitás és az egy nemzethez tartozás különösen a hiányzó piaci ismeretek esetén könnyítette meg a befektető vállalatok helyzetét. A 100\%-ban magyar tulajdonú vállalatok mellett a helyi gazdasági szereplőkre támaszkodva vegyes vállalatok is létrejöttek a megyében, amelyekbe partnerként az ott élő magyar kisebbség tagjait vonták be. A válaszadók a Kárpátalja által

4. ábra: Kárpátalja helyspecifikus előnyei Location-specific advantages provided by Transcarpathia

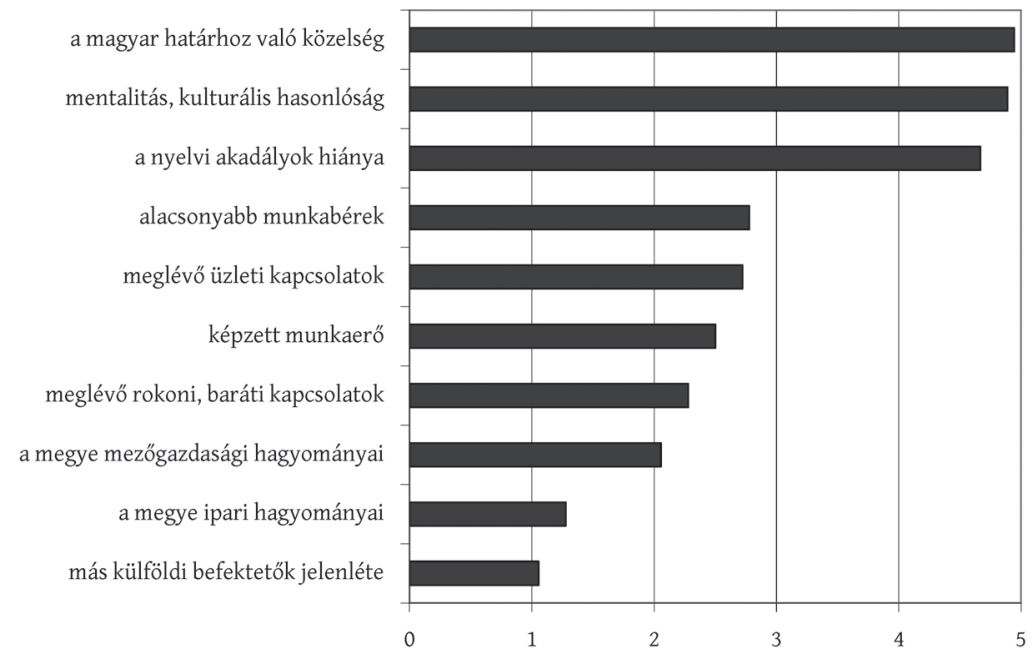

Megjegyzés: A kérdöiven a válaszadók 1 és 5 között értékelhették, hogy milyen különleges vonzerövel rendelkezett a térség a befektetö vállalat szempontjából. Míg az 1-es érték azt fejezi ki, hogy a térséghez kötődo” elöny nem volt lényeges a befektetó vállalat számára, addig az 5-ös érték azt jelenti, hogy az adott elöny fontos volt a tőkét kihelyezô magyar cégnek. Az ábra a húsz vállalat válaszainak átlagos értékeit tünteti fel. 
nyújtott egyedi előnyök közül ismételten kiemelték az ukrajnai viszonylatban is alacsony munkabéreket, a térség gazdasági szereplőihez füződő korábbi üzleti (esetleg rokoni és baráti) kapcsolatokat, melyek azonban a földrajzi és kulturális közelségnél kevésbé befolyásolták a befektetési döntéseket.

\section{A magyar tőkével müködő kárpátaljai vállalatok jellemzői}

A megkérdezett, magyar tőkével működő kárpátaljai vállalatok a magyar határral közvetlenül szomszédos területeken (az ungvári, a beregszászi, a munkácsi és a nagyszőlősi járásban) találhatók, amit a magyar határhoz való közelség és a magyar kisebbség magas részaránya mellett az is magyaráz, hogy ezek a járások az ukrán régió legfejlettebb területei, itt találhatók Kárpátalja legjelentősebb városai és a régió ipari és mezőgazdasági termelési kapacitásainak nagy része is itt koncentrálódik. A magyar befektetők többsége nem a gazdasági szempontból legdinamikusabban fejlődő Ungvárt és az ungvári járást preferálta, hanem a magyar többségű Beregszász városában és a beregszászi járásban létesített vegyes- vagy leányvállalatokat. (A mintában szereplő vállalatok közül 11 cég választotta ezt a területet.)

A megkérdezett kárpátaljai vegyes- és leányvállalatok közül 16 céget a 2002-2008 közötti időszakban alapítottak, mindössze 4 olyan vállalkozás volt, amelyet korábban hoztak létre. Hat cég teljesen magyar tulajdonban van, míg 14 vállalat számára a helyi partnert is bevonó vegyes vállalati forma volt megfelelő, ahol a befektetők általában a többségi tulajdont részesítették előnyben. A teljes vagy többségi tulajdon választása gyakoribb az ukrán piacról nagyobb ismerettel rendelkező vállalkozások körében, de az aszimmetrikus kapcsolatok kialakítására magyarázatot jelenthet a magyar vállalatok nem túl erős tulajdonspecifikus előnye is. Az ilyen tulajdonosi szerkezet biztosítja ugyanis legnagyobb mértékben a tulajdonspecifikus előnyök védelmét. Azokat a vállalatokat, amelyek a helyi partner nagyobb mértékủ bevonása mellett döntöttek, elsősorban az üzleti környezet ismeretének a hiánya, a partner helyi adminisztrációs és üzleti kapcsolatai motiválták. A kisebbségi magyar tulajdon elsősorban a helyi önkormányzati partnereket bevonó, valamint az értékesítő vegyes vállalatok esetében volt jellemző.

A Kárpátalján magyar tőkével létesített vegyes- és leányvállalatok jellemzően a kelet-európai piacokon bonyolítják eladásaikat: 11 cég csak az ukrán piacon van jelen, kettő az ukrán mellett az orosz piacot is ellátja, további kettő pedig csak az orosz piacra termel. A Kárpátalján működő leány- és vegyes vállalatok ugyanis az ukrán vásárlókat vámmentesen, az orosz piacot pedig jóval alacsonyabb vámtételek megfizetése mellett láthatják el. Az ukrán piacot megcélzó vállalatok egy csoportja (3 cég) csak Kárpátalján értékesít: ezek a vállalatok helyhez kötött szolgáltató tevékenységet (ivóvízszolgáltatás, hulladékkezelés) folytatnak, amelyhez részben a térségben korábban kiépített infrastrukturális hálózatot veszik igénybe. 
A Kárpátalján befektető magyar vállalatok a hazaitól teljes mértékben eltérő üzleti környezetbe kerülnek. Ebben a bizonytalan befektetési környezetben kiemelkedően fontos szerep jutott a vállalkozók Kárpátalján élő magyar kisebbség tagjaihoz füződő személyes kapcsolatainak. A kérdőíves vizsgálat szerint hét magyar vállalatnál korábbi üzleti kapcsolatok könnyítették meg a kárpátaljai befektetést, míg hat kisebb cégnél rokoni-baráti kapcsolatok is közrejátszottak. További két vállalkozásnál vállalkozásfejlesztési központ (vagy kereskedelmi és iparkamara) segítségével valósult meg a beruházás. Az üzletember-találkozók, kiállítások és vásárok a megkérdezett magyar befektetők közül két céget segítettek a tőkekivitelben, míg az önkormányzatok három vállalatnál működtek közre a kárpátaljai vegyes- vagy leányvállalat létrehozásában. (Az önkormányzati részvétellel létrejött befektetési kapcsolatok a vizsgált mintában erőteljesen felülreprezentáltak voltak, amelynek az oka az ilyen jellegű vállalkozások könnyebb elérhetősége volt.)

\section{Összegzés}

Kárpátalja Magyarországgal kiépített külgazdasági kapcsolatai a térségben élő magyar kisebbségnek köszönhetően sokkal erőteljesebbek bármely más ukrán megyénél: Magyarország Kárpátalja legfontosabb exportpartnere, a magyar-ukrán vegyes vállalatok bejegyzésének gyakorisága pedig a tőkekapcsolatok intenzitásáról tanúskodik. A magyar tőke Kárpátaljára áramlása a kilencvenes évek második felében volt a legdinamikusabb, ezeket a tőkekihelyezéseket azonban még nem a magyar gazdasági szereplők valós ukrajnai befektetési szándéka, hanem a körbeáramló tőke magyarázza. A magyar vállalatok megerősödésének, az ukrajnai piacgazdasági viszonyok megszilárdulásának és a határőrizeti rendszer szigorodásának együttes eredményeképpen a körbeáramló tőke jellegű befektetések fokozatosan csökkentek és napjainkra már a ténylegesen befektetési céllal kihelyezett magyar eredetű külföldi múködő tőke is megjelent Kárpátalján.

A magyar vállalkozók befektetési döntései során elsősorban a piaci motivációk voltak meghatározók, hiszen a termelés és értékesítés külföldre történő kihelyezésével megnyílt számukra az ukrán piac, valamint a Független Államok Közössége belső vámkedvezményeinek köszönhetően az orosz piac is. A kárpátaljai magyar tőkebefektetések kapcsán nem is annyira ukrán-magyar, mint inkább magyar-magyar tőkekapcsolatokról beszélhetünk, mivel a jellemző vegyes vállalati forma esetében az ukrán partner a helyi magyar kisebbség tagjai közül került ki. Ezt támasztja alá az a tény is, hogy a megkérdezett vállalatok müködőtőke-befektetéseik döntő többségét az ukrán régió magyarlakta területein, elsősorban Beregszász városában és a beregszászi járásban valósították meg.

A Kárpátalján befektető magyar vállalatoknak számolniuk kell azzal, hogy a hazaitól eltérő, bizonytalan befektetési környezetbe kerülnek. Ebben a kockázatos 
és bizonytalan üzleti környezetben a magyar vállalkozások tőkeerősebb nyugateurópai (például osztrák) versenytársakkal szembeni előnye abból származik, hogy a térségben élő magyar kisebbség tagjaihoz füződő vagy a rendszerváltás előttre visszanyúló üzleti kapcsolataiknak köszönhetően rendelkeznek azokkal a piaci információkkal, amelyek befektetéseik biztonságát és sikerességét biztosíthatják. Kárpátalja komparatív előnyeit tehát a magyar vállalatok olyan csoportja tudja kihasználni, amely jól ismeri a helyi viszonyokat, tisztában van az ukrán gazdaság íratlan szabályaival vagy megbízható partnereinek köszönhetően el tud igazodni a jogi bizonytalanságok útvesztőiben. A földrajzi közelség a kérdőíves vizsgálat tanúsága szerint meghatározó tényező a piaci informáltság szempontjából, hiszen a Kárpátalján befektető vállalatok többségének az Ukrajnával szomszédos magyar megyében, Szabolcs-Szatmár-Beregben van a székhelye. A magyar-ukrán határtól távolabbi területekről érkező vállalkozásoknál pedig az esetek többségében kimutatható a kárpátaljai magyar kisebbség tagjaihoz füződő személyes kapcsolat.

Ahhoz, hogy a jövőben újra meginduljon a Kárpátaljára kihelyezett magyar tőkeállomány növekedése, illetve hogy még több magyar kis- és középvállalat lásson befektetési lehetőséget a határ menti ukrán megyében, mindenekelőtt az Ukrajnában általánosan jellemző üzleti környezetnek kell befektetőbarátabbá válnia. Ezen pedig elsősorban nem a befektetők vonzását szolgáló törvények javítgatása tud segíteni, hanem a piacgazdasági viszonyok meggyőző jelenléte, a reformfolyamat eddiginél következetesebb és hatékonyabb megvalósítása. Ukrajna ígéretes befektetési piac a magyar vállalkozások számára, már csak méretéből adódóan is, hiszen önmagában akkora, mint összes többi szomszédunk együttvéve. Az ukrán gazdaság a 2014. évi politikai és gazdasági válságot követően feltehetően ismét az európai átlagot meghaladó fejlődési pályára áll, amelyből megfelelő feltételek esetén a magyar vállalkozói réteg is profitálhat. Mivel a hazai piac vásárlóereje feltehetően nem változik jelentősen az elkövetkező időszakban, a tőkekivitel (az egyértelmű kockázatok mellett) növekedési és jövedelemstabilizációs lehetőséget jelent a külpiacra lépésre érett magyar kis- és középvállalkozások számára, különösen az olyan ágazatokban, mint az agrárium, az információtechnológiai és a szolgáltatási szektor, az élelmiszeripar vagy a gépgyártás. A magyar-ukrán határ feltehetően hosszabb ideig az EU külső határa, gazdasági rendszerek közötti határ marad, éppen ezért mindkét oldal számára kulcskérdés a határ menti gazdasági együttmúködés fejlesztése.

\section{Jegyzetek}

$1 \quad$ Ez az írás kibővíti és új elemekkel gazdagítja egy korábban megjelent publikációmat (Imre 2013), azonban a téma megértetése érdekében helyenként ismétlésekbe kellett bocsátkoznom.

2 A Kárpátalja nem hivatalos, de a helyi magyar szóhasználatban évtizedek óta elfogadott név, politikai-közigazgatási értelemben, földrajzi és tájnévként egyaránt. Tanulmányomban a terület megnevezésére ezért a továbbiakban ezt a kifejezést fogom használni. 
3 A két országban a működő tőke számítási módszertana eltérő, ezért a becslések csupán közelítő képet adhatnak. Mivel azonban a Magyar Nemzeti Bank csak az Ukrajnába irányuló magyar tőke összegét tartja nyilván és nem közli ennek regionális megoszlását, a Kárpátalján befektetett magyar működő tőke aránya a teljes ukrajnai állományból csak az ukrán régió statisztikai hivatalának adatai segítségével becsülhető. A MNB statisztikája szerint 2000-ben 16,2 millió eurónyi magyarországi múködő tőke áramlott Ukrajnába, miközben a Kárpátaljai Statisztikai Hivatal 16,4 millió USD értékủ magyar befektetést regisztrált. 2009-ben az MNB adatai szerint 362,5 millió eurónyi működőtőke-befektetést hajtottak végre magyarországi vállalkozások Ukrajnában, miközben a Kárpátalján befektetett hazai tőke csupán 34,7 millió USD-t tett ki.

4 A körbeáramló tőke jelensége kapcsán gyakran hivatkozott nemzetközi példa a Kínában befektetett, statisztikailag tajvani, eredetét tekintve azonban szárazföldi kínai tőke, amelyet ugyancsak a külföldi vállalkozásoknak nyújtott előnyök megszerzése, valamint az ellenőrzések kikerülése céljából fektetnek vissza kínai vállalkozásokba.

\section{Irodalom}

Dunning, J. H. (1993): Multinational enterprises and the global economy. Addison Wesley, Reading

Dunning, J. H., Narula, R. (1996): The investment development path revisited - Some emerging issues. In: Dunning, J. H., Narula, R. (eds.): Foreign direct investment and governments: Catalysts for economic restructuring. Routledge, London, 1-34.

Hardi T. (2001): Néhány földrajzi elmélet alkalmazása a Kárpát-medence határtérségeire és a határ menti együttmúködéseire. In: Dormány G., Kovács F., Réti M., Rakonczai J. (szerk.): A földrajz eredményei az új évezred küszöbén. A Magyar Földrajzi Konferencia 2001 CD kiadványa. SZTE, Szeged

Imre, G. (2013): The characteristics of the Hungarian FDI invested in Transcarpathia. Central European Regional Policy and Human Geography, 2., 31-40.

Johanson, J., Vahlne, J.-E. (1990): The mechanism of internationalisation. International Marketing Review, 4., 11-24.

Johanson, J., Wiedersheim-Paul, F. (1975): The internationalization of the firm - four Swedish cases. Journal of Management Studies, 3., 305-322.

Kárpátaljai Magyar Vállalkozók Szövetsége (2013): Kárpátalja gazdaságfejlesztési stratégiai terve. Beregszász

Ludvig, Zs. (2007): Hungarian-Ukrainian economic relations: Overview of the past one and half decade. EU Working Papers, 3., 30-52.

Статистичний щорічник Закарпаття 2007. Ужгород, 2008

Svetličič, M. (2003): Theoretical context of outward foreign direct investment from transition economies. In: Svetličič, M., Rojec, M. (eds.): Facilitating transition by internationalization: Outward direct investment from Central European economies. Ashgate, Aldershot, 3-16.

Svetličič, M., Jaklič, A., Burger, A. (2007): Internationalization of small and medium-size enterprises from selected Central European economies. Eastern European Economics, 4., 36-65.

http://www.mnb.hu, a Magyar Nemzeti Bank weboldala

http://www.uz.ukrstat.gov.ua, a Kárpátaljai Statisztikai Hivatal weboldala 


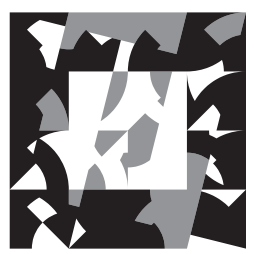

TÉR ÉS TÁRSADALOM | SPACE AND SOCIETY 